\title{
Peran Antioksidan pada Non Alcoholic Fatty Liver Disease (NAFLD)
}

\author{
Yusri Diane Jurnalis, Yorva Sayoeti, Elfitrimelly
}

\begin{abstract}
Abstrak
Nonalcoholic Fatty Liver Disease (NAFLD) merupakan penyebab tersering penyakit hati kronik pada anak dan remaja diseluruh dunia. NAFLD berhubungan dengan obesitas, diabetes melitus tipe 2 dan sindrom metabolik. Resistensi insulin memegang peranan penting dalam patogenesis molecular terjadinya NAFLD. Ketidakseimbangan prooksidan dan antioksidan pada sel hepatosis menentukan progresifitas penyakit ini. Sebagai antioksidan telah dilakukan penelitian mengenai efek antioksidan vitamin $\mathrm{E}$, vitamin $\mathrm{C}$, betaine, $\mathrm{N}$-asetil sistein, probucol dan silymarin. Antioksidan tersebut memperlihatkan perbaikan fungsi hepar dan gambaran histopatologis.
\end{abstract}

Kata kunci: Arial 9 NAFLD, resistensi insulin, antioksidan

\begin{abstract}
Nonalcoholic fatty liver disease (NAFLD) is the most common cause of liver disease in pediatric and adolescent population. NAFLD related with obesity, type 2 diabetes mellitus and metabolic syndrome. Insulin resistance and oxidative stress have important role in molecular pathogenesis of NAFLD. Prooxidant and antioxidant factor in hepatosit can determine progressivity of liver disease. As antioxidant agent for treatment NAFLD have been studied effect of vitamin $E$, vitamin $C$, betaine, $N$-acetyl cystein, probucol and sylimarin. They have been shown improvement of liver function test and histopathologycal feature.

Keywords:NAFLD, insulin resistance, antioxidant
\end{abstract}

Affiliasi penulis : Bagian IImu Kesehatan Anak Fakultas Kedokteran Universitas Andalas

Korespondensi : Yusri Diane Jurnalis, email

yusridiane@yahoo.com, Telp/Hp : 081363931569

\section{PENDAHULUAN}

Nonalcoholic Fatty Liver Disease (NAFLD) merupakan penyebab tersering penyakit hati kronik pada anak dan remaja di seluruh dunia. Angka kejadian meningkat terutama pada anak yang mengalami obesitas (22,5\%-528\%). ${ }^{1-4}$ NAFLD dilaporkan mengenai $2,6 \%$ populasi anak didunia, $20 \%$ anak dan remaja dengan obesitas di Amerika Serikat, $44 \%$ di Italia dan $74 \%$ di Cina. Penyakit ini berhubungan dengan diabetes melitus tipe 2 dan sindrom metabolik.,

NAFLD meliputi beberapa derajat penyakit mulai dari steatosis ringan sampai Nonalcoholic steatohepatitis (NASH) yang dapat menyebabkan fibrosis lanjut, sirosis, bahkan karsinoma hepatoseluler. Resistensi insulin dan stres oksidatif memegang peranan penting dalam patogenesis NAFLD. ${ }^{2-4}$ Stres oksidatif terjadi bila senyawa oksidan diproduksi lebih banyak dibandingkan proses antioksidan yang mampu dilakukan oleh hepar. ${ }^{4}$

Saat ini strategi pengobatan untuk pasien yang menderita NAFLD meliputi identifikasi dan tatalaksana penyakit metabolik yang terkait seperti obesitas, diabetes dan dislipidemia, memperbaiki resistensi insulin melalui penurunan berat badan, olahraga dan farmakoterapi, serta penggunaan obatobat hepatoprotektor seperti antioksidan untuk melindungi hepar dari proses stres oksidatif. Sebagai antioksidan untuk terapi NAFLD, telah dilakukan uji terhadap vitamin $\mathrm{E}$, betaine, $\mathrm{n}$-asetil sistein, probucol dan vitamin $\mathrm{C}$. Vitamin $\mathrm{E}$ memperlihatkan aktivitas antioksidan yang kuat secara in vivo. 5,6
Oleh karena itu, penting untuk mengetahui peran antioksidan sebagai terapi pada anak yang menderita NAFLD.

\section{Non Alcoholic Fatty Liver Disease (NAFLD)}

NAFLD adalah suatu kondisi akumulasi lemak yang berlebihan pada hepar pada individu yang meminum sedikit alkohol maupun tidak. ${ }^{7}$ Insidens NAFLD pada anak adalah $2,6 \%$ dan $53 \%$ diantaranya adalah anak dengan obesitas. 4,8

Angka kejadian NAFLD sangat bervariasi, NAFLD dilaporkan mengenai anak usia 2-19 tahun. ${ }^{2}$ Gejala klinis NAFLD pada anak hampir sama dengan dewasa. Namun pada anak sering dijumpai gejala yang asimtomatis. Sering anak terdiagnosis setelah melakukan pemeriksaan kadar aminotransferase untuk skrining penyakit yang berhubungan dengan obesitas. NAFLD yang khas ditemukan pada anak usia 11-13 tahun, laki-laki dengan berat badan lebih atau obesitas. Manifestasi klinis yang paling sering adalah rasa tidak nyaman pada perut kanan atas dan letih. Pada anak sering ditemukan obesitas dan hepatomegali. Adanya achantosis nigricans merupakan marker resistensi insulin yang ditemukan pada kulit. Sirosis yang merupakan progresifitas dari NAFLD dapat mengenai anak usia 10 tahun. Lamanya menderita obesitas merupakan determinan untuk progresif menjadi sirosis. ${ }^{1,3,8,9}$

Pada NAFLD ditemukan peningkatan kadar aminotransferase serum yang ringan sampai berat $( \pm$ 6-7 kali dari nilai normal). Kadang-kadang dapat juga dijumpai kadar aminotransferase serum yang normal walaupun hasil biopsi menunjukkan gambaran NAFLD. Pada keadaan terdapatnya peningkatan aminotransferase, perlu dilakukan pemeriksaan ultrasonografi bila dicurigai menderita NAFLD. Biopsi hepar merupakan baku emas untuk diagnosis NAFLD. 
Biopsi lebih akurat untuk menentukan derajat penyakit dan membedakan NASH dengan simple steatosis. ${ }^{3}$ Karakteristik NAFLD ditandai oleh akumulasi lemak dalam sel hepar yang hampir mengenai $5 \%$ dari hepatosit. bila terdapat akumulasi lemak tanpa adanya inflamasi disebut simple steatosis. ${ }^{4,5,7}$ Pada nonalcoholic steatohepatitis (NASH), akumulasi lemak dihubungkan dengan inflamasi sel hepar dan derajat parut yang berbeda. NASH merupakan kondisi yang serius yang menyebabkan parut hepar yang hebat dan sirosis.

\section{Patogenesis NAFLD}

Patogenesis NAFLD masih belum jelas sejak awal penyakit ini ditemukan. Berbagai hipotesis menjelaskan mekanisme patogenesis NAFLD seperti perbedaan distribusi lemak atau sistem antioksidan. Terdapat "two-hit theory yang mengawali mekanisme patogenesis dan progresifitas NAFLD/NASH. Teori yang pertama adalah akumulasi lemak pada penderita obesitas atau resistensi insulin, sementara teori yang kedua adalah induksi sitokin inflamasi akibat stres oksidatif, peroksidasi lipid dan endotoksin. Kedua teori ini menyebabkan kematian sel, infiltrasi sel inflamasi dan fibrosis hepar. Kerusakan mitokondria juga terlibat pada stres oksidatif dan reactive oxygen species diproduksi dalam jumlah besar. ${ }^{3}$

Peranan resistensi insulin pada progresifitas penyakit NAFLD atau NASH masih belum jelas. Kecepatan pembentukan glukosa oksidatif dan non oksidatif berkurang secara bermakna pada pasien yang mengalami NASH. Hal ini memperlihatkan tingginya kebutuhan insulin untuk mempertahankan kadar gula darah normal. Sehingga sekresi insulin meningkat untuk menurunkan kadar glukosa.

Patogenesis molekuler dari resistensi insulin adalah multifaktorial dan beberapa target molekuler terlibat dalam menghambat kerja insulin. ${ }^{8}$ Resistensi insulin disebabkan ketidakmampuan jaringan adiposa untuk mengatasi keadaan kelebihan lemak. Ketidakmampuan ini menyebabkan pelepasan yang berlebihan adipositokin yang memperberat resistensi insulin sehingga terjadi vicious cycle.

Insulin bekerja melalui perantara protein substrat reseptor insulin. Thyrosine phosporilation yang terdapat pada substrat reseptor insulin akan mengaktivasi tiga jalur utama yaitu:

1. Jalur PI3K-Akt yang terlibat dalam metabolisme glukosa, lemak dan protein.

2. Jalur MAPK yang mengaktivasi pertumbuhan dan diferensiasi sel.

3. Jalur $\mathrm{CAP} / \mathrm{Cb} / \mathrm{Tc} 10$ pada otot yang mengatur translokasi membran (Glucose transporter 4, GLUT4).

Aktivasi jalur PI3K-Akt di hepar menyebabkan abnormalitas supresi lipolisis, meningkatkan glukoneogenesis dan lipogenesis. Lipogenesis disebabkan karena pengaturan faktor-faktor transkripsi lipogenik seperti sterol regulatory binding protein-1c
(SREBP-1c) dan carbohydrate response element binding protein (CREBP). Pada subjek yang sehat, kontribusi lipogenesis saat puasa kurang dari $5 \%$ dan meningkat secara signifikan setelah makan. Pada penderita NAFLD, lipogenesis meningkat secara signifikan pada keadaan puasa (mencapai $26 \%$ dari kecepatan normal) dan gagal meningkat pada respons setelah makan. Lipogenesis menyebabkan pembentukan pool asam lemak di hepar. Berkurangnya kecepatan transpor lemak hepar disebabkan menurunnya sintesis dan ekskresi apolipoprotein $B$, sehingga cadangan lemak menumpuk dalam hepar., Pada NAFLD, seperti halnya resistensi insulin, asam lemak dari jaringan adiposa tidak ditekan oleh insulin dan asam lemak plasma menjadi meningkat. Sehingga pada anak yang menderita NAFLD sering mengalami hipertrigliseridemia, kadar $\mathrm{HDL}$ rendah, dan LDL tinggi.

Jalur kompensasi akibat penumpukan lemak yang berlebihan di hepar dan otot adalah aktivasi beta oksidasi asam lemak mitokondria karena desensitisasi dari carnitine palmitoyltransferase (CPT-I) yang merupakan gerbang yang mengatur masuknya asam lemak rantai panjang ke dalam mitokondria. Sebagian besar elektron-elektron berperan dalam rantai respirasi dan bermigrasi sepanjang rantai respirasi ke cytochrome $c$ oxidase. Ketidakseimbangan antara input elektron yang tinggi dan pembatasan aliran elektron menyebabkan reduksi yang berlebihan pada kompleks I dan III rantai respirasi. Hal inilah yang mendasari kompleks-kompleks yang tereduksi akan bereaksi dengan oksigen untuk membentuk reactive oxygen species (ROS).

Berkurangnya oksigen pada kompleks I dan III menghasilkan radikal anion superoksida yang mengalami dismutasi menjadi hidrogen peroksida (H2O2) oleh enzim superokida dismutase (MnSOD). ROS mengoksidasi asam lemak tidak jenuh yang menyebabkan lipid peroksidasi membentuk produkproduk seperti 4-hydroxynonenal (HNE) dan malondialdehyde (MDA). ROS dan produk-produk reaktif aldehid lipid peroksidasi secara langsung merusak DNA mitokondria dan polipeptida rantai respirasi.

Selanjutnya, produksi ROS yang berlebihan meningkatkan ekspresi beberapa sitokin-sitokin (TNF$\alpha$, transforming growth factor beta;(TGF beta), Fas ligand, IL-8) yang mampu mengaktivasi kaspase dan meningkatnya permeabilitas mitokondria, infiltrasi netrofil, dan sintesis kolagen dalam sel hepar. Bahanbahan antioksidan terutama glutation secara cepat dikonsumsi, namun tidak mencukupi untuk mentralkan peningkatan kadar ROS sehingga mengakibatkan nekroinflamasi. ROS menyebabkan apoptosis sel secara langsung melalui aktivasi NF-kB.

Beberapa sinyal lain yang berasal dari jaringan adiposa seperti leptin dan TNF- $\alpha$ memperberat proses inflamasi hepatik. (gambar 1$)^{3}{ }^{3}$ 


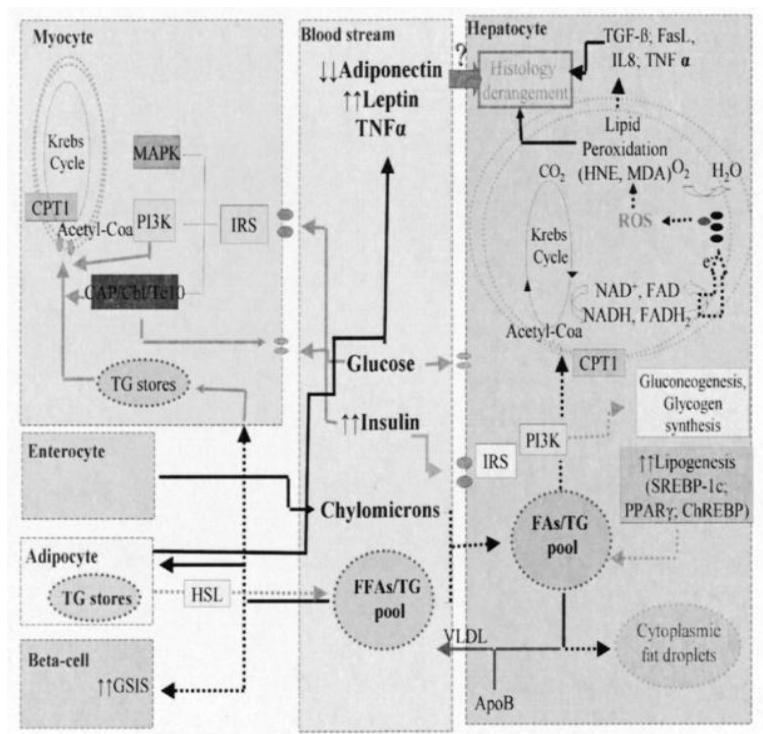

Gambar 1. Kerusakan jalur metabolik pada NAFLD ${ }^{3}$ Antioksidan

Antioksidan merupakan suatu molekul yang dapat memperlambat atau mencegah oksidasi molekul lainnya. Reaksi oksidasi menghasilkan radikal bebas yang dapat menyebabkan kerusakan sel. Antioksidan dapat menetralkan radikal bebas. ${ }^{11}$

Radikal bebas adalah suatu atom, gugus atom atau molekul yang memiliki satu atau lebih elektron yang tidak berpasangan pada orbital paling luar. Radikal bebas pada umumnya bersifat tidak stabil dan sangat reaktif. Beberapa bentuk senyawa oksigen radikal bebas diantaranya superoksida, hidroksil, peroksil $\left(\mathrm{RO}_{2}-\right)$, alkoksil (RO-), hidroperoksil $\left(\mathrm{HO}_{2-}\right)$, nitrit oksida dan nitrogen dioksida $\left(\mathrm{NO}_{2}\right)$. Oksigen dan nitrogen radikal bebas dapat dirubah menjadi spesies reaktif non radikal seperti hidrogen peroksida, asam hipoklorat dan peroksinitrit. Reactive oxygen species (ROS) dan reactive nitrogen species (RNS) diproduksi oleh hewan dan manusia dibawah kondisi fisiologis dan patologis. ${ }^{12}$

Radikal bebas memiliki peranan penting dalam kehidupan alamiah sel dan evolusi biologi. Radikal bebas dapat berperan pada transduksi sinyal, transkripsi gen dan pengaturan aktivitas guanilat siklase dalam sel. Radikal bebas berperan dalam oksidasi biomolekul-biomolekul seperti protein, asam amino, lipid dan DNA yang menyebabkan kerusakan dan kematian sel. Efek sitotoksik radikal bebas Reaksi utama produksi oksigen dan nitrogen radikal bebas diperlihatkan pada gambar $2 .{ }^{12}$

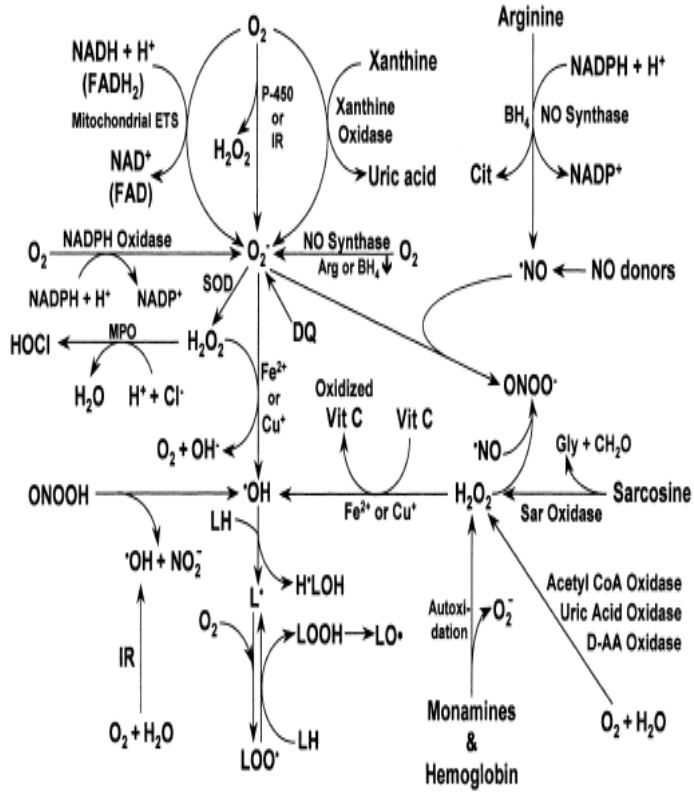

Gambar 2. Produksi oksigen dan nitrogen radikal bebas dalam sel ${ }^{12}$

Pada kondisi fisiologis, hampir 1-3\% oksigen dikonsumsi tubuh dirubah menjadi superoksida dan ROS lainnya. Dalam siklus kehidupan, setiap manusia berisiko mengalami stres oksidatif yang diinduksi oleh tingginya konsumsi oksigen, aktivasi autoimun sel sistem imun dan faktor-faktor lingkungan. Keterpaparan jangka panjang terhadap radikal bebas, meskipun dalam kadar rendah menyebabkan mutasi DNA, kerusakan jaringan dan penyakit. Sistem pertahanan terhadap radikal bebas berupa enzim (superoksida dismutase, glutation, glutation peroksidase, glutation reductase, katalase) dan makanan yang mengandung antioksidan. ${ }^{12}$

\section{Antioksidan pada NAFLD}

\section{a. Vitamin $\mathrm{E}$}

Vitamin $\mathrm{E}$ adalah vitamin yang larut dalam lemak, secara in vivo memperlihatkan aktivitas yang kuat sebagai antioksidan. Vitamin $\mathrm{E}$ memiliki struktur mirip cincin dengan rantai samping isoprene, terbagi atas dua kelompok yaitu tokoferol dengan satu rantai samping isoprene yang jenuh dan tokotrienol dengan tiga ikatan yang tidak jenuh pada rantai samping. Masing-masing terdiri atas empat isomer $(\alpha, \beta, \gamma$ dan $\delta)$ 
menyebabkan vitamin $E$ terdiri atas 8 jenis. 6,13

Tokoferol- $\alpha$ merupakan jenis antioksidan yang paling potensial. Kadar tokoferol- $\alpha$ dalam plasma dipertahankan untuk tetap tinggi. Hepatosit terdiri atas $\alpha$ tocopherol transfer protein ( $\alpha$-TTP) yang berikatan dengan tokoferol- $\alpha$. Tokoferol diabsorbsi oleh usus halus dan mencapai hepar melalui ikatannya dengan kilomikron. Dalam hepar, tokoferol- $\alpha$ berikatan secara selektif dengan $\alpha$-TTP, kemudian berikatan dengan very low density lipoprotein (VLDL) dan beredar dalam darah. Proses ambilan tokoferol- $\alpha$ oleh $\alpha$-TTP dalam hepar merupakan kunci utama dalam mempertahankan kadar tokoferol- $\alpha$ dalam sirkulasi. Keadaan gangguan fungsi $\alpha$-TTP menyebabkan defisiensi vitamin E. Pada manusia terdapat defisiensi vitamin $E$ familial yang disebabkan oleh defek pada gen $\alpha$ TTP. ${ }^{6}$

Vitamin $E$ digunakan dalam tatalaksana NAFLD, namun bagaimana mekanisme kerjanya masih belum diketahui. ${ }^{6}$ Vitamin $E$ merupakan antioksidan yang mencegah kerusakan sel melalui ikatannya dengan radikal bebas dan menetralisasi elektron yang tidak berpasangan. Bila vitamin $\mathrm{E}$ berikatan dengan $\mathrm{OO}^{-}$atau $\mathrm{O}_{2}$, akan membentuk struktur intermedietnya yaitu $\alpha$ tocopherylquinone (gambar 3$).{ }^{13}$

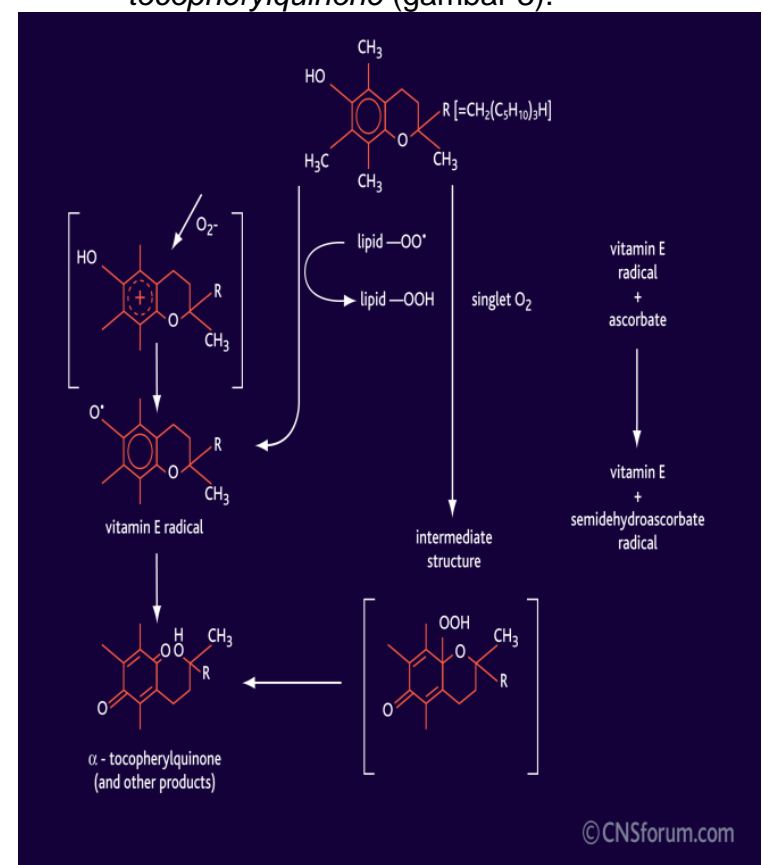

Gambar 3. Mekanisme vitamin E sebagai antioksidan $^{13}$
Vitamin E merupakan antioksidan yang dapat menstabilkan membran-membran biologis melalui efek protektifnya terhadap proses lipid peroksidase asam lemak tidak jenuh dan reaksi radikal bebas. $\alpha$-tokoferol merupakan bentuk vitamin E yang dapat dimetabolisme manusia, menghambat produksi transforming growth factor beta 1 (TGF- $\beta 1$ ) dan melemahkan stimulasi sitokin terhadap sel-sel stelata yang menyebabkan fibrosis. Penelitian Hasegawa dan kawankawan (2001) dengan memberikan vitamin $\mathrm{E}$ $300 \mathrm{mg}$ per hari selama 1 tahun memperlihatkan penurunan yang bermakna kadar TGF- $\beta 1$, dan normalisasi kadar enzimenzim hepar dan perbaikan steatosis, inflamasi dan fibrosis pada biopsi hepar. ${ }^{14,1}$

Pemberian vitamin E pertama kali dilakukan terhadap 11 anak obesitas yang menderita NAFLD dengan dosis 400-1200 IU/hari selama 6 bulan, hasil memperlihatkan perbaikan kadar serum aminotransaminase tanpa tergantung perubahan berat badan. Namun kadar serum aminotransferase meningkat kembali setelah penghentian terapi vitamin $E^{3,16}$ Vajro dan kawan-kawan (2000) juga mendapatkan perbaikan kadar serum aminotransaminase setelah pemberian vitamin $E$ setelah 2 bulan, namun tidak terdapat perubahan gambaran histopatologi. Manco dan kawan-kawan (2008) merekomendasikan vitamin $\mathrm{E}$ hanya pada penderita NAFLD yang memiliki berat badan normal. Pada penelitian kohort 90 biopsi anak yang terbukti NAFLD/NASH, setelah mendapat suplementasi antioksidan vitamin E $600 \mathrm{IU} /$ hari dan vitamin C $500 \mathrm{mg} /$ hari tidak memperlihatkan perbedaan yang bermakna pada gambaran histologi, kadar enzim hepar dan ultrasonografi, dibandingkan pemberian plasebo. ${ }^{3}$ Lavine dkk (2011) melaporkan efek pemberian vitamin E $800 \mathrm{IU} /$ hari bersamaan dengan metformin $1000 \mathrm{mg}$ hampir sama dengan efek plasebo dalam menurunkan kadar alanin transaminase (ALT) selama 96 minggu. ${ }^{17}$ Tabel 1 memperlihatkan beberapa penelitian tentang efek vitamin $\mathrm{E}$ pada penderita NAFLD/NASH pada anak dan dewasa yang telah dipublikasikan. ${ }^{15}$ 
Tabel 1. Penelitian tentang efek vitamin $E$ pada penderita NAFLD/NASH ${ }^{15}$

\begin{tabular}{|c|c|c|c|c|c|c|}
\hline $\begin{array}{c}\text { Author } \\
\text { (year) }\end{array}$ & $\begin{array}{l}\text { Desi } \\
\text { gn }\end{array}$ & $\begin{array}{l}\text { Interventi } \\
\text { on }\end{array}$ & $\begin{array}{l}\text { Compa } \\
\text { rator }\end{array}$ & $\begin{array}{l}\text { Dura } \\
\text { tion, } \\
\text { mont } \\
\text { hs }\end{array}$ & $\begin{array}{l}\text { Histo } \\
\text { logy }\end{array}$ & $\begin{array}{l}\text { AL } \\
T\end{array}$ \\
\hline $\begin{array}{l}\text { Sanyal } \\
\text { et al } \\
2010\end{array}$ & RCT & $\begin{array}{l}\text { Pioglitazo } \\
\text { ne }(n=80) \\
\text { or vitamin } \\
E(n=84)\end{array}$ & $\begin{array}{l}\text { Placeb } \\
0 \\
(n=83)\end{array}$ & 24 & + & + \\
\hline $\begin{array}{l}\text { Yakary } \\
\text { ilmaz } \\
\text { et al } \\
(2007)\end{array}$ & $\mathrm{OL}$ & Vitamin $\mathrm{E}$ & & 6 & + & + \\
\hline $\begin{array}{l}\text { Dufour } \\
\text { et al } \\
(2006)\end{array}$ & RCT & $\begin{array}{l}\text { Vitamin E } \\
+\quad \text { UDCA } \\
(n=15)\end{array}$ & $\begin{array}{l}\text { UDCA } \\
+ \\
\text { placebo } \\
(n=18) \\
\text { or } \\
\text { placebo } \\
+ \\
\text { placebo } \\
(n=15)\end{array}$ & 24 & + & + \\
\hline $\begin{array}{l}\text { Bugian } \\
\text { esi et } \\
\text { al } \\
(2005)\end{array}$ & RCT & Vitamin $\mathrm{E}$ & $\begin{array}{l}\text { Metfor } \\
\text { min or } \\
\text { diet }\end{array}$ & 12 & - & + \\
\hline $\begin{array}{l}\text { Sanyal } \\
\text { et al } \\
(2004)\end{array}$ & RCT & Vitamin E & $\begin{array}{l}\text { Vitamin } \\
\mathrm{E}^{+}+ \\
\text {pioglita } \\
\text { zone }\end{array}$ & 6 & + & - \\
\hline $\begin{array}{l}\text { Harriso } \\
n \text { et al } \\
(2003\end{array}$ & RCT & $\begin{array}{l}\text { Vitamin C } \\
+\quad \text { vitamin } \\
E(n=23)\end{array}$ & $\begin{array}{l}\text { Placeb } \\
0 \\
(n=22)\end{array}$ & 6 & - & - \\
\hline $\begin{array}{l}\text { Haseg } \\
\text { awa et } \\
\text { al(200 } \\
\text { 1) }\end{array}$ & OL & Vitamin E & - & 12 & + & + \\
\hline $\begin{array}{l}\text { Lavine } \\
\text { et al } \\
(2000)\end{array}$ & $\mathrm{OL}$ & Vitamin E & - & $4-10$ & $\mathrm{~N} / \mathrm{A}$ & + \\
\hline
\end{tabular}

\section{b. Vitamin C (Asam Askorbat)}

Vitamin $C$ atau asam askorbat merupakan senyawa enam buah carbonlactone yang disintesis dari glukosa pada hepar sebagaian besar mamalia, bukan pada manusia, primata dan babi. Karena spesies ini tidak memiliki enzim gulonolactone oksidase yang berperan dalam sintesis asam askorbat. Sehingga bila manusia tidak mengkonsumsi vitamin $\mathrm{C}$, defisiensi akan terjadi dengan berbagai spektrum klinis. Vitamin C merupakan donor elektron atau agen pereduksi. Asam askorbat memberikan dua elektron dari ikatan ganda antara karbon kedua dan ketiga. Vitamin $\mathrm{C}$ disebut sebagai antioksidan karena kemampuannya mendonorkan elektron, mencegah senyawasenyawa lain dari proses oksidasi. Vitamin C bekerja pada lipid, membran lipid, protein dan DNA sel. Vitamin C bereaksi dalam menurunkan reactive oxygen species (ROS) dan menghambat proses lipid peroksidase. ${ }^{18}$

Vitamin C terutama ditemukan dalam buah-buahan dan sayuran. Sebagai suplemen, vitamin $\mathrm{C}$ tersedia dalam bentuk tablet dan serbuk. ${ }_{18}$ Dietary Reference Intake Panel of the Institute of Medicine merekomendasikan diet vitamin $\mathrm{C}$ yang disarankan adalah $90 \mathrm{mg} /$ hari untuk laki-laki dewasa dan $75 \mathrm{mg} / \mathrm{hari}$ untuk wanita dewasa, sedangkan untuk remaja usia 14-18 tahun laki-laki $75 \mathrm{mg} /$ hari dan perempuan 65 $\mathrm{mg} / \mathrm{hari}$ dengan dosis maksimal 1.000 $\mathrm{mg} /$ hari. Vitamin $\mathrm{C}$ di metabolisme di hepar melalui oksidasi dan sulfasi serta di eliminasi lewat urin. $\pm 85 \%$ dari dosis yang di absorbsi di ekskresikan melalui urin. Dosis $>2 \mathrm{~g} /$ hari dapat menyebabkan diare dan batu ginjal sehingga dosis $1 \mathrm{~g} /$ hari merupakan batas konsumsi perhari yang aman. ${ }^{19}$

Penambahan terapi antioksidan seperti asam askorbat selain intervensi pola hidup didasari oleh pengetahuan tentang stress oksidatif yang menyebabkan steatosis sederhana, steatohepatitis, fibrosis dan sirosis. Stress oksidatif akan memperkuat resistensi insulin. Penelitian pada anak dengan memberikan vitamin E 600 IU dan vitamin C $500 \mathrm{mg} / \mathrm{hari}$ memperlihatkan perbaikan fungsi hati dan gambaran histopatologi. $^{3}$

\section{c. Betaine}

Betaine adalah suatu metabolit choline, yang meningkatkan kadar S-adenosyl-Lmethionine (SAM) yang memperkuat integritas membran sel dan melindungi sel dari infiltrasi lemak pada hewan coba. Pada hepar, betaine merupakan faktor hepatoprotektor., ${ }^{4,9}$ Betaine biasanya dapat dijumpai pada makanan seperti jus buahbuahan yang dapat digunakan dalam tatalaksana NAFLD. Betaine disintesis secara in vivo dari oksidasi choline.

Betaine biasanya digunakan untuk mengobati gangguan metabolisme homosistein pada anak. Pada penderita NAFLD dewasa betaine telah digunakan, namun pemberian pada anak belum diteliti. Efeknya pada NAFLD telah diperlihatkan pada beberapa penelitian klinis menggunakan betaine anhidrat cairan oral atau sebagai kapsul. Abdelmalek dan kawankawan telah meneliti tentang efek pemberian oral larutan betain anhidrat dua kali sehari selama 1 tahun pada 10 penderita NASH dewasa dengan melakukan biopsi. Meskipun terdapat perbaikan pada kadar transaminase, namun perubahan histologi dan fibrosis tidak bermakna. ${ }^{9,20}$ Penelitian pada dewasa dengan memberikan cairan oral betaine anhidrat 20 gram/hari dibagi dua dosis selama 12 bulan memperlihatkan perbaikan fungsi hati dan gambaran histopatologi. Dosis optimal dan bentuk sediaan betaine yang dapat diberikan pada penderita NAFLD masih belum jelas. $^{20}$

\section{d. N-asetil-sistein}

$\mathrm{N}$-asetilsistein merupakan suatu senyawa thiol yang bereaksi sebagai scavenger radikal bebas dan prekursor gluthatione yang melindungi hepar dari stres oksidatif melalui peningkatan kadar glutathione. Peningkatan kadar glutathione sebaliknya akan membatasi produksi reactive oxygen species (ROS). Glutathione merupakan antioksidan non protein utama dalam sel yang berperan dalam detoksifikasi radikal bebas. Pada penderita NAFLD kadar glutathione meningkat. Gulbahar dan kawan-kawan meneliti tentang efek $\mathrm{N}$-asetil-sistein pada 11 pasien dewasa dan melaporkan adanya perbaikan pada kadar transaminase, namun tidak terdapat perubahan histopatologi. 
Pengobatan NASH dengan dosis 1 gram per hari selama 3 bulan terhadap 11 pasien $\mathrm{NASH}$ dewasa memperlihatkan perbaikan fungsi hati yang signifikan pada akhir periode pengobatan. Meskipun $\mathrm{N}$-asetil sistein memperlihatkan perbaikan fungsi hati, mekanismenya masih belum jelas. ${ }^{21}$

e. Silymarin

Silymarin merupakan ekstrak flavolignan dari buah dan biji-bijian tanaman Silybum marianum. Sylimarin memiliki efek antioksidan dan hepatoprotektor. Suatu penelitian tentang efek Sylimarin pada penderita NAFLD juga diperoleh perbaikan kadar enzim-enzim hepar dan resistensi insulin, bila kapsul silybinin $94 \mathrm{mg}$ diberikan bersamaan dengan kapsul vitamin E $90 \mathrm{mg}$ dan kapsul fosfolipid $194 \mathrm{mg}$ dengan dosis empat kapsul setiap hari. Penelitian lebih lanjut harus dilakukan sebelum merekomendasikan penggunaan sediaan ini. ${ }^{14,15}$

\section{f. Probucol}

Probucol merupakan antioksidan yang dapat menurunkan kadar lipid. Pada penelitian Merat dan kawan-kawan (2003) diperoleh hasil perbaikan kadar serum aminotransferase dibandingkan kelompok yang diberikan plasebo selama 6 bulan pengamatan. Namun, probucol tidak tersedia dan pernah dihentikan pemberiannya di Australia dan Amerika Serikat akibat potensi pro aritmia. ${ }^{5}$

\section{KESIMPULAN}

Pemberian terapi antioksidan pada penderita NAFLD dapat memperbaiki fungsi hepar serta gambaran histopatologi. Namun tidak semua antioksidan memberikan hasil yang memuaskan, untuk itu perlu dilakukan penelitian lebih lanjut.

\section{DAFTAR PUSTAKA}

1. Moore EA. The fight against fatty liver disease. Diunduh dari: Cewebsource.com. tanggal 24 Maret 2012.

2. Feldstein $A E$, Charatcharoenwitthaya $P$ Treeprasertsuk S, Benson JT, Enders FB, Angulo $P$. The natural history of non-alcoholic fatty liver disease in children: a follow-up study for up to 20 years. Gut.2009;58:p.1538 44.

3. Manco M, Bottazo GF, DeVito R, Marcellini M, Mingrone G, Nobili V. Nonalcoholic fatty liver disease in children. Journal of American College of Nutrition.2008;27(6):p. 667-76.

4. Collantes R, Ong JP, Younossi ZM. Non alcoholic fatty liver disease and the epidemic of obesity. Cleveland clinic journal of medicine.2004;71(8):p.657-64.

5. Adams LA, angulo P.Treatment of nonalcoholic fatty liver disease. Postgrad med J.2006;82:315-22.

6. Takitani K, Miyazaki H, Yoden A, Tamai H. Children's toxicology from bench to bed-Liver injury(2): Mechanism of antioxidant therapy for nonalcoholic fatty liver disease.J. Toxicol.Sci. 2009; 34 . SP223-SP228.
7. Feldstein $\mathrm{AE}$, Kay MH. Fatty liver disease. The American College of Gastroenterology. Diunduh dari: www.acg.gi.org. Tanggal 19 April 2012.

8. Angulo $\mathrm{P}$. Nonalcoholic fatty liver disease. $\mathrm{N}$ Engl J Med.2002;346(16):p.1221-31.

9. American Gastroenterology Association. AGA technical review on Nonalcoholic Fatty Liver Disease. Gastroenterology.2002;123:p.170525.

10. Quercioli A, Montecucco F, Mach F. Update on the Treatments of Non-Alcoholic Fatty Liver Disease (NAFLD). Cardiovascular \& Haematological Targets.2009;9:p.261-270

11. What are Antioxidants?. Diunduh dari: www.news-medical.net/health. Tanggal 19 April 2012.

12. Fang $Y Z$, Yang $S, W u$ G. Free radicals, antioxidants and nutritions. Nutrition.2002;18:p.872-9.

13. Mechanism of action of antioxidants, vitamin E. Diunduh dari: www.cnsforum.com. Tanggal 20 April 2012.

14. Duvnjak M, Tomasic V, Gomercic M, Duvnjak LS, Barsic N, Lerotic I. Therapy of nonalcoholic fatty liver disease: current status. Journal of Physiology and pharmacology.2009;60(7):p.57-66.

15. Satapathy SK, Sanyal AJ. Novel treatment modalities for non alcoholic steatohepatitis. Trends in Endocrinology and Metabolism.2010;21(11):p.668-75.

16. Kerkar N. Non-alcoholic steatohepatitis in children. Pediatr Transplantation 2004;8:p.613-8.

17. Lavine JE, Schwimmer JB, Van Natta ML, Molleston JP, Murray KF et al. Effect of Vitamin $E$ or Metformin for Treatment of Nonalcoholic Fatty liver disease in Children and Adolescent. JAMA.2011;305 (16):p.165968.

18. Padayatty SJ, Katz A, Wang Y, Eck P, Kwon $\mathrm{O}$, Lee $\mathrm{JH}$ et al. Vitamin $\mathrm{C}$ as an antioxidant: Evaluation of its role in disease prevention. Journal of the american college of nutrition.2003;22(1):p.18-35.

19. Hathcock JN, Azzi A, Blumberg J, Bray T, Dickinson $A$, Frei $B$, Jialal I et al. Vitamins $E$ and $C$ are safe across a broad range of intakes. Am J Clin Nutr.2005:81:p.736-45

20. Mukherjee S. Betaine and nonalcoholic statohepatitis: Back to the future?. World $\mathrm{J}$ Gastroenterol.2011;17(32):3663-4.

21. Thong-Ngam D, Samuhasaneeto S, Kulaputana O, Klaikeaw N. N-acetylcysteine attenuates oxidative stress and liver pathology in rats with non-alcoholic steatohepatitis. World J Gastroenterol. 2007; 13(38): 5127-32. 